which they were erected, has effectually disposed of the possibility of profitable excavation. Here, however, a find of vessels of copper and implements of bronze and iron has afforded instructive evidence of agricultural practice in Syria in the Byzantine age. At Sheikh Yusuf al Gharib further evidence was afforded of the activity of the port in the second half of the fourth century B.C., in the form of merchants' magazines, which had been burned, but had preserved a detailed picture of trade. A lamp store was stocked with lamps of both the imported and the locally made varieties, lamp fillers and Syrian oil bottles copying Greek models, while the stock of painted Attic aryballi bore witness to a common origin in common characteristics which made it possible to trace a definite shipment by a single firm and to date it within a few years. Gold and silver beads and silver coins of Athens, copper ingots and loose quicksilver marked a jeweller's shop. Back to the ninth century this is the most important Greek colony so far excavated. The absence of evidence from the earlier Mycenæan age is to be attributed to the forces of Nature, which have washed away the earlier portions of the site. Yet there is a link in a local copy of a Mycenæan vase and a single sherd of fine hand-made burnished black ware, which alone would suggest an earlier date. Though no inscription has been found, it is suggested that this is the ancient Posidium, mentioned by Herodotus as founded before the Mycenæan age.

\section{Bronze Age Burials in Scotland}

A NUMBER of bronze age burials with some remarkable and unusual features, recently disclosed by building operations at Doonfoot, Ayr, and at Riccarton, Ferniegair, Lanarkshire, are described by Mr. Ludovic Mann in The Scotsman of July 20. At Doonfoot, no evidence of a cairn was discovered, but at Ferniegair, a structure of stone, of which the overground portion had been demolished, had covered a group of burials. Some eighty tons of loose stones, some water-rolled, formed an understructure in which horizontal layers of turf had filled the interstices and survived in the form of black carbonized matter. Both cemeteries have yielded pottery vessels of various types, assignable to successive phases of the bronze age and, therefore, pointing to an occupation covering a considerable period of time. The earliest form is a small squat hand-made food-vessel, with incised and impressed zonal ornament. Traces of carbonized cereal adhere to the interior. The bodies had been placed in the contracted position, looking toward the rising, or, in one instance, the setting sun, at Midsummer. Over one body at Ferniegair was sheeting made from the twisted and plaited stems of the Scottish moss, Polytrichum commune. Other examples of this textile material have been found at Mount Vernon, Glasgow, in a bronze age cairn near Stranraer, and a few weeks ago at Craignish, Argyll. Mr. Mann states that the dimensions of the stones of the tomb structures conform with an ancient linear measure, as do the interior dimensions of the chamber; and also that the position of the urn-fields, and other remains, ancient roads and tracks, conform, in a geometrical convention, also based on a common unit. Both at Doonfoot and Riecarton, adjoining burials contained large cinerary urns, with eremated remains, inverted over squared stone slabs. These overlie burials of the earlier inhumation period. At Doonfoot three burials were superimposed. A further find recorded is at Catacol, Lochranza, Arran, where a six-foot skeleton was found in the extended position in a long narrow chamber, constructed of small side slabs and heavy roofing stones. An iron object was found with the body.

\section{The National Central Library}

THE twelfth annual report of the National Central Library refers to anxiety regarding the financial position of the Library due to inability to replace from any other source the $£ 4,000$ previously received as an annual grant from the Carnegie United Kingdom Trust. Fortunately, the Treasury grant-in-aid has been increased from $£ 3,000$ to $£ 5,000$ for a period of five years from April 1, 1936, and as a result the Carnegie Trustees have renewed their previous annual grant for a similar period. The continuance of both grants is conditional upon an increase in annual subscriptions from libraries by at least $£ 2,000$ by March 31, 1938. In consequence of the financial situation, expenditure on books has been only $£ 2,338$ but in addition to 3,110 volumes purchased, 5,451 volumes have been presented. The total number of volumes lent during the year was 118,288 and there are now 158 outlier libraries containing 6,303,000 volumes from which 10,002 volumes were borrowed. Reference is also made in the report to the extension of the regional system to cover the counties of Cornwall, Devon, Dorset, Gloucester, Hampshire, Oxford, Somerset and Wiltshire. When this system is established, the whole of England and Wales will be covered in eight regional systems, in addition to the London Borough libraries inter-lending system. Volumes lent to university libraries increased by 97 to 2,506 . The system was used by $\mathbf{5 3}$ university libraries and 1,201 of the volumes were supplied by the National Central Library, 77 by foreign libraries and 1,228 by other university libraries, 80.52 per cent of the inquiries being supplied. The books supplied consist mainly of highly specialized and expensive books, books out of print, foreign books, back numbers of periodicals, or unpublished university theses.

\section{National Research Council of Canada}

TwE eighteenth annual report of the National Research Council, Dominion of Canada, covers the activities of the Council in 1934-35. During the year, the Associate Committees on Aeronautical Research and on Trail Smelter Smoke were re-organized and three important conferences were held, one on problems of the honey industry, another to formulate a programme of cold-storage investigations, and the third to investigate the potato situation and the utilization of a surplus. The work at the laboratory for laundry research conducted by the Council since 1930 has now led to the formation of a Canadian 
Research Institute of Launderers and Cleaners. Reports from the various laboratory divisions summarizing work in progress refer to investigations on chemical weed killers, including a review of the literature, and on the biochemistry of rust resistance. The Division of Chemistry has devoted a considerable amount of attention to problems relating to carbon black, leather, paints and rubber. It has developed a method for plucking poultry which has received many favourable notices. A special wax has been prepared which can be used for removing the penfeathers, and by its use poulterers can prepare birds for market which are cleanly plucked and attractive. Much work has been done on the conservation of Alberta's natural resources, while in the Fire Hazard Testing Laboratory of the Division of Physics and Engineering, the testing and listing of domestic oil burners has been studied and the drafting of safety codes has received attention. A joint Associate Committee with the Dominion Department of Agriculture has investigated field crop diseases while another such committee is concerned with grain research including the frost injury of wheat, methods of determining moisture in grain and the effect of carbon tetrachloride on the quality of damp wheat in storage. Other associate committees are concerned with the storage and transport of food, weed problems, wool, parasitology and engineering standards.

\section{Organon}

THE first number of a new international review, Organon, has just been published in Warsaw by the Mianowski Institute. It is printed in French and English although all the authors are Polish, in order that a wide public may become familiar with the progress of scientific thought in Poland. The general character of the new publication can be gathered from the first group of contributions-"The Science of Science", "La Science, la religion et l'art", "The Man of Action and the Student", "Documents sur la psychologie de l'invention dans le domaine de la science", "Science and Scholarship in Poland to the Close of the Sixteenth Century", "Copernic", "Organisation de la science polonaise" and "Marja Sklodowska-Curie". The term 'science' is used in the widest possible sense, so that the new review will not be limited to contributions dealing only with the natural sciences. Two of the four historical articles have for their subjects the best known of Polish scientific workers, namely, Copernicus and $\mathrm{Mme}$. Curie. It will be observed that the international character of science is well illustrated by the life and work of Mme. Curie. Polish by birth and French by marriage, her great discoveries were made with material from Bohemia which had been put at her disposal by Austrian authorities.

\section{The Science of Science}

THE first contribution to Organon attempts to analyse the 'science' of scientific investigations. We are reminded that the problems of science can be grouped according to different principles. Thus, they may be classified as being connected with the philosophy of science, with its psychology or with its sociology. Such groupings and others in which further subdivisions are made do not avoid overlapping but, according to Drs. M. and S. Ossowski, they do serve to indicate that there can be a 'science of Science'. Against this view it can be urged that these problems already have their positions in welldefined fields (psychology, sociology, the theoretical parts of the separate sciences, etc.) but the Polish authors argue that the scope of this 'science of Science' comprises investigations concerning very widely separated subjects and brings them into internal harmony. The problems are attacked by many different means, but even here new links can be forged to bring the whole of science into one harmonious whole. The growth of science requires an extremely wide and many-sided supplementary apparatus, and the building of this apparatus requires theoretical studies.

\section{A Landmark of Horticulture}

THE names of J. C. Loudon and his wife Jane Loudon will always be remembered gratefully by gardeners. Such exhaustive publications as the "Encyclopædia of Plants", the "Encyclopædia of Gardening", and the "Encyclopædia of Agriculture" led up to their culminating triumph, the "Arboretum et Fruticetum Britannicum". This was published in sixty-eight parts between January 1835 and July 1838, so that it is approximately one hundred years since this typographical monument was given to the public. Mr. W. Roberts, writing on "The Centenary of Loudon's 'Arboretum'" (J. Roy. Hort. Soc., 61, Part 7, July 1936), gives some interesting information about the methods by which the extraordinary amount of knowledge upon trees and shrubs was brought together. About three thousand questionnaires were circulated, in the days before the penny post, and Loudon received a very gratifying number of replies, the originals of which have been consulted by Mr. Roberts. Many of them bear striking testimony to the popularity of the Loudons, for invitations to stay at country seats were very numerous. An application to the Duke of Wellington resulted in his Iordship mistaking the word Beeches for Breeches, and the signature for C. J. London. This he interpreted as from the Bishop of London, and accordingly dispatched the famous Waterloo breeches to that puzzled gentleman. The "Arboretum" and the other publications contain a great deal of information which is still of the greatest use at the present time. It is inevitable that the march of knowledge should add considerably to these solid foundations, but one feels that the $£ 10,000$ which the Loudons paid in amassing the knowledge and publishing the text of the "Arboretum" are still bearing handsome interest for the horticultural fraternity.

\section{Survey of India}

THE General Report of the Survey of India for 1935 directs attention to the need for quicker revision of the maps of India. It was in 1905 that the Survey embarked on a scheme of 1 inch to 1 mile maps of 